\title{
INTRODUCTION
}

\section{Imagining Social Justice amidst Guatemala's Post-Conflict Violence}

\section{Gabriela Torres, Wheaton College, MA}

Violence $^{1}$, whether it is understood as individual acts of aggression, structural inequality, or direct acts of coercion by the state, always encompasses injustice. In Central America, the postwar period that was begun in the last decade of the twentieth century has been mired by multiple and compounding forms of violence that have magnified injustice. One of the most basic injustices is the reality that residents of Guatemala City - joined by the residents of its closest urban neighbours of San Salvador and Tegucigalpa as well as many of their counterparts in other large Latin American cities - live in fear of armed assaults and other arbitrary crimes that often end in murder (Caldeira, 2000; Rotker, 2002).

A survey of Guatemalan families conducted prior to a rise in crime rates after 2004 indicates the level of insecurity: 42 percent of respondent families reported that at least one of their members had been a victim of a crime in 2004 (Plataforma de Investigación y Diálogo Intersectorial para el Diseño de una Política de Seguridad Ciudadana (POLSEC), 2004). Just over 80 percent of the crimes reported by these families were armed robberies that did not result in physical injury and that took place mainly in city streets mostly between the hours of 8 a.m. and 6 p.m. when individuals tend to engage in shopping and work-related activities. 99 percent of the robberies reported by Guatemalan families took place within the municipal limits of Guatemala City. Amazingly, the threat of robbery was found close to home as 50 percent of the robberies took place within the city zone in which the individual resided.

A more recent a survey of Guatemala City residents that was conducted quarterly from 2006 to 2007 also demonstrates a growing concern with insecurity. In this survey, 40 percent of residents reported that they expected to be the victim of a violent crime within six months (PNUD, 2007b). Interestingly, when the same survey asked if the residents had witnessed a violent crime within the last six months, between 40 and 45 percent of respondents responded positively in the 2006-

\footnotetext{
1 Violence is conceived in this issue in adherence to Bourgois' suggestion that social science literature has categorized the breadth of social relationships that "buttress inequalities of power" into four interrelated conceptual categories (Bourgois 2004). He suggests that the conceptualizations of violence in social science can be arranged into four general categories: direct political violence as is it generally discussed in political science literature, Galtung's (1975) sense of structural violence, Bourdieu's (1997) conception of symbolic violence and SheperHughes (1992) understanding of everyday violence (Bourgois 2004). All four expressions of violence are discussed by the authors in this collection but Menjivar focuses primarily on everyday and symbolic forms of violence, while Drysdale Walsh and Godoy-Paíz focus on symbolic and structural violence. For Bourgois as for the authors in this collection, these four expressions of violence are intricately interrelated and in practice the increased intensity of one form of violence sustains and expands its other forms of expression.
} 
2007 period (PNUD, 2007b). This is a sharp rise in violence given that in 2004, only 35 percent of respondents had witnessed a violent crime within the six months prior to the survey (PNUD, 2007b; POLSEC 2004).

Guatemala is undoubtedly undergoing a crisis of "civic insecurity" that is characterized by a combination of high and rising levels of violence, a pervasiveness of impunity ${ }^{2}$, and an inability to comprehensively address the root causes of its post-conflict instability. The inability to find workable approaches to ameliorate what the country's government calls "citizen insecurity" is not just a problem for official state institutions. Effectively addressing post-conflict violence is also a problem for organizations and individuals working to promote social justice in the Central American region (WOLA, 2006). Whereas conflict resolution and attenuation were logical focal points for social justice promotion in the later part of the $20^{\text {th }}$ Century, today social justice work needs to revisit the root causes that spurred conflict in the region in the first place.

Guatemala's legacy of engrained social suffering, economic inequality, and gender disparity, among other social justice concerns, was left largely unaddressed by the peace process. As Manolo Vela and Juan Hernández Pico have eloquently argued, Guatemala's peace process came almost as a decreed afterthought (Hernández Pico, 2005). It came to be an act (rather than a process) that sought to consolidate a nominal democratic transition that was developed without civil society consultations and was explicitly designed to leave the country's economic or cultural legacies of violence unaddressed (Vela, Senquén-Mónchez \& Solares, 2001). In 2007, 56 percent of Guatemalans were living under the poverty line. Inequality measures for the region show that in Guatemala, the country with widest income disparity in the region, the poorest 20 percent of the population share in 2.9 percent of the national income while the richest 20 percent have access to 59.5 of the same (PNUD, 2007a). Nicaragua, the country in the region that followed a more contested process of democratic transition with some degree of civil society participation, now has the smallest income gap in the region where the poorest 20 percent of the population share 5.6 percent of the national income while the richest 20 percent have access to 49.3 percent of the same (PNUD, 2007a). Interestingly, where high rates of social inequality were present, criminal violence now seems to be working to magnify its social costs. The figures for El Salvador, a country with a more comparable democratic transition and peace process, are similar to Guatemala where the poorest 20 percent share in 2.7 percent of national income and the richest in 55.9 percent of the same (PNUD, 2007a).

In Guatemala, violence is costly from a number of perspectives. In terms of foreign investment losses, the region's current poor rankings in the indices suggest that Guatemala is less than an ideal choice for foreign capital (Estado de la Región, 2008). Though the social costs of violence are unquantifiable (Kleinman, Das \& Locke, 1997), estimates that have been made using figures such as direct health care expenditures, investment and material losses as well as increased investment in private and public security and law enforcement are useful in that they can suggest what the minimal societal impact of rising levels of violence can be. United Nations estimates of

\footnotetext{
${ }^{2}$ According to the United Nations Commission on Human Rights, impunity is "the impossibility, de jure or de facto, of bringing the perpetrators of violations to account - whether in criminal, civil, administrative or disciplinary proceedings - since they are not subject to any inquiry that might lead to their being accused, arrested, tried and, if found guilty, sentenced to appropriate penalties, and to making reparations to their victims" (United Nations Human Rights Commission, 2005).
} 
the economic and social costs of the post-conflict violence crisis in the region suggest that the levels of violence experienced in 2006 cost 7.6 percent of Guatemala's GDP in that same year (PNUD, 2006; Estado de la Región, 2008). In the country with the highest rates of violence in the region-El Salvador - violence has cost close to 11.5 percent of that country's annual GDP since 2003 (PNUD, 2005; Estado de la Región, 2008).

These figures give a sense of the possible extent of the long term repercussions of violence in the region, and suggest that the current crisis of violence will inevitably have a widespread impact. Resources that might have been used for social programs are diverted to responding and reacting to the strain of violence on institutions. Looking at the social costs of violence with a qualitative lens, Moser and McIlwaine estimate that rising gang and interpersonal violence levels seen early in the post-conflict setting could work to erode families' ability to successfully participate in economic pursuits and to adequately support the education, health and nourishment of the next generation of Guatemalans (Moser \& McIlwaine, 2001). In her essay in this collection, Menjivar picks up where the estimates leave off - by addressing the personal costs of violence and the meanings of social suffering caused by violence in a rural ladino community.

Drysdale Walsh and Godoy-Paiz in this issue address the growing complexity of the postconflict situation of the region by looking at the sources of violence that can no longer be easily identified. Following patterns set by repressive regimes in the region during the 1980s, transnational and local gangs as well as organized crime syndicates have joined states in the use of violence and terror as a tool in their regular business practice (WOLA, 2006). Non-state organizations - including the aforementioned gangs, and organized crime syndicates as well as quasi-police forces and even some rural communities - now engage in the quotidian use of violent acts to enact social control. In these contexts, violent acts have had multiple uses ranging from effective tools of governance to controversial forms of public justice (Godoy-Paiz, 2006; Sanford, 2003). Yet, what such violent acts have in common, is that perpetrators of violence are seldom sought or prosecuted, and only very rarely punished (Godoy-Paiz, 2006). Analysts argue that it is perhaps the entrenchment of impunity into the social life of some Central American states that has enabled the proliferation of social actors practicing violence (Krujit \& Koonings, 1999).

Given the continuing concern with inequality in the region, the collection of papers presented here works to understand how the promotion of social justice is possible amidst the complexity of Central America's post-conflict violence. Focusing on the ways that violence is lived, understood and addressed in Guatemala, this collection of papers is a starting point for thinking through solutions to post-conflict violence that address social justice concerns for the region as a whole. Because Guatemala presents higher levels inequality and violence in the region, it is a good starting point from which to suggest ways that social justice can be attained through the crafting of policies that take into account "local" or "grassroots" understandings and practices of life with violence and injustice. Addressing social justice concerns through local or indigenous knowledge allows analysts and policymakers to take into account the compounding effects of different forms of violence and to address the concerns that Central Americans find most pressing in their everyday lives. 


\section{Guatemala in the Regional Context of Post-Conflict Violence}

Violence in the Central American region today is not uniform. The northernmost countries of the region (Guatemala, Belize, Honduras and El Salvador), suffer from much higher rates of crime and interpersonal violence than their southern counterparts. Though the system devised for reporting of homicides in Central America allows for a wide divergence between accepted, actual, and official homicide figures, the homicide rates estimated from official police records in 2006, are 56, 45 and 42 per hundred thousand people for El Salvador, Guatemala and Honduras, respectively (OCAVI, 2007a; Programa Estado de la Región, 2008). In comparison, the homicide rates for the same period for Costa Rica and Nicaragua were significantly less at 8 and 13 respectively (OCAVI, 2007a; Programa Estado de la Región, 2008). On average, the homicide rates of the northern part of the Central American region are more than eight times the U.S. homicide rate and twenty-five times Canada's homicide rate in the same year calculated at 6.1 and 1.9 per hundred thousand respectively (Department of Justice, 2006; Human Resources and Social Development Canada, 2008). Current homicide rates have risen at alarming rates particularly in the two post-conflict countries of El Salvador and Guatemala which boast increases of 48 percent and 75 percent respectively since the signing of peace accords (OCAVI, 2007b).

High rates of violence, however, are not directly associated with civil war legacies, as Nicaragua diverges from the high current indices of violence in post-war Guatemala and El Salvador. The region's differing textures and levels of violence might be derivative of the different ways that conflicts were managed and "pacified" in the region. Increasing levels of violence might be indicative of a number of factors including the geopolitical role of the northern part of Central America for drug trafficking or the pervasiveness of impunity in the national legal systems. Still, it seems counterintuitive that although the civil wars of the 1980s found nominal resolutions, residents of the region's northernmost countries continue to live within the seemingly insurmountable spectre of violence and insecurity now outside of the context of war.

The papers in this collection suggest that post-conflict violence in Guatemala is on the rise because violent interaction has come to find a cultural and legal path through which it can become understood as a norm. Addressing social justice concerns in this context requires an understanding of how violence comes to be acceptable and quotidian through institutional, legal and cultural practices.

\section{Violence and Social Justice}

Given the region's shockingly high rates of crime and violence, the growth in social actors perpetrating violence, the variation in the social uses and understandings of violent acts, and the prevalence of impunity, one may ask if it is still possible to imagine an approach to violence attenuation in the region that is based on principles of social justice?

The key to a social justice approach in the region lies in understanding how impunity makes the routine practice of violence possible. Analysts - and our informants - have suggested from early on that it is the prevalence of systems of impunity in the region that is likely responsible for the proliferation of social actors engaged in violence (Krujit \& Koonings, 1999; see Drysdale Walsh in this collection). Yet, having perpetrators of violent acts routinely going unpunished 
and, in most cases, not even prosecuted for crimes can also cause a proliferation in the types of violent acts that have characterized the region since Peace Accords were signed in Guatemala and El Salvador. Given the proliferation of perpetrators of violent acts and types of violence, what alternatives are left for to attenuate violence? Are manodurismo ${ }^{3}$ or other forms of social dictatorships viable alternatives to reduce violence? Is limpieza social or social cleansingcommonly authored by communities, paramilitaries and organized crime - now the only solution? Or can violence be addressed through an adherence to social justice ideals?

This collection of papers suggests that violence attenuation in the region is possible in adherence with social justice principles if we focus on local understandings of violence. Local knowledge on how violence is lived and spoken about by individuals and how it comes to be defined and addressed by institutions and individuals is key to developing strategies that support social justice. Accepting the primacy of local understandings requires coming to terms with the ways that violence can come to be expressed and accepted in understated and sometimes contradictory ways. Menjivar's discussion of illness and Drysdale Walsh and Godoy-Paiz' discussions of Guatemalan women's inability to rely on state authorities for safety are two examples of how individuals are forced to accept and understand violence that is present in their lives. Focusing on local understandings also requires appreciating the breadth of local practices through which violence is extended. This is discussed by Godoy-Paiz' assessment of the role that Guatemala's legal restructuring has played in femicide maintenance, Drysdale Walsh's account of the role of police and the attitudes of justice officials in the arbitration of domestic violence, and by Menjivar's discussion of how town gossip works to extend social control.

Yet understanding the local experience of violence detailed in the ethnographic accounts and case studies presented in the collection is not enough to construct a social justice approach to violence attenuation in the region. Impunity systems ${ }^{4}$, both in Guatemala in particular and in the region as a whole, must be understood as obstructions to social justice. Systems of impunity working through the selective applications of legal or social sanction (as described by Drysdale Walsh's informants) are a priori based on manipulation and prioritization of multiple forms of social injustice. Social injustices promoted by systemic impunity in the region - for example, gender-based discrimination through femicide, or governance through the control of brute force by gangs and crime syndicates - do more than make multiple expressions of violence possible. Systemic impunity anticipates increasing levels and types of violence. It extends and expands acts of violence into a social norm and forces systems of governance to incorporate what should be the state of exception.

From the point of view of anthropology, impunity systems are of interest not just because they promote social inequalities but because they build inequality by further entrenching culturally accepted forms of discrimination. Prior to engaging with the arguments found in the other papers in this collection, I want to briefly suggest the role that impunity plays to reconstitute

\footnotetext{
${ }^{3}$ Manodurismo as a socially sanctioned form of social control supports private acts of vigilantism, high levels of state-sponsored violence against those who come to be defined as criminals and populist "strongmen" leadership often accompanied by an open disregard for human rights concerns (Godoy, 2006).

${ }^{4}$ Impunity systems include the active naturalization and social acceptance of multiple forms of violence as forms of culture, inefficient, contradictory, un-enforceable and inappropriately constructed laws as well as inadequacies in law enforcement personnel, a lack of institutional supports for citizen-driven solutions, and inadequate levels funding for law enforcement and crime prevention programs.
} 
Guatemala's social life. In keeping with the gender focus of the papers in the collection, I use the case of femicide in Guatemala as an illustration of how impunity works to advance violence and inequality by building on culturally accepted forms of intolerance and difference. Briefly examining the concept and practice of impunity, I suggest that successful violence attenuation is possible if impunity systems in the region are targeted as key obstructions to social justice.

\section{The Practice of Impunity}

Femicide, defined as the processes through which violence against women becomes socially accepted and quotidian (Russell, 1976), embodies the complexities of how impunity continues to be practiced in the context of post-conflict violence in the region. First labelled in Mexico, the problem of femicide has gained currency for the region's governments as foreign aid agencies have become eager to fund solutions to femicide throughout the Central American region and academic analyses have rushed to condemn its practice (Grais-Targow, 2004; Constantino, 2006). The pervasiveness of femicide in the region relies on a complex historical, cultural, and institutional legacy of gender-based discrimination (Aguilar, 2005). In Guatemala, the number of femicides rose from 213 in 2000 and 383 in 2003 to 665 in 2005 and is now in numerical decline to 605 in 2006 and 590 in 2007.

As stated earlier, Guatemala's overall murder rates are extremely high and the murder of women is but a fraction of the total number of murders. Men are in fact at least ten times more likely to be killed than women. According to an article published in the Prensa Libre on January 22, 2008, entitled "Reportan 76 Asesinatos en los Primeros Ocho Días del Mandato de Colom," just as femicide has grown, the murders of men too have been growing from 2,904 in 2000 to a height of 5,885 in 2006, with a small reduction to 5,781 in 2007 (OCAVI, 2007a). What is astonishing in the murders of both men and women is the number of cases that are not investigated and remain unsolved. In 2007, Guatemala's Supreme Court, the Crown Prosecutor's Office and the Government Ministry sponsored a detailed case study of 553 random murders (Fernández, 2008). Only three of the 553 murders - a rate just under $0.2 \%$ - ever saw prosecution in a courtroom. Looking at the murder records that could have been used to develop a legal file for prosecution, the same study found that half of the records were missing photographic evidence of the crime scene, a third of the records had no indication that forensic evidence from a medical doctor was collected, and in another third of the files no scientific substantiation of the evidence had been attempted (Fernández, 2008). Perpetrators of murder in Guatemala function with impunity that demonstrates not just the state's tolerance of multiple forms of violence (despite its research initiatives) but the extent to which violence has become naturalized into Guatemalan society.

Nevertheless, as analyzed by Berger and reviewed by Drysdale Walsh in this collection, the prevalence of impunity in Guatemala has begun to be questioned as international and national opposition to femicide coalesce in the context of Guatemala's complex women's rights movement (Berger, 2006). The impunity system that supports the country's high murder rate is rarely emphasized. Police make arrests (and not all who are arrested are prosecuted) in only two percent of the more than 5,000 homicides each year in Guatemala (Menocal, 2006). More disturbingly, in the case of gender-based violence, impunity is even more pervasive; of the 2,300 femicide cases between 2000 and August 2006, only seventeen had been resolved and some of 
those were exonerations. Even in exceptionally heinous cases, impunity systems prevail amidst public outcry, as in the case of the murder of a mother and her three girls detailed in a newspaper account in Prensa Libre on September 28, 2007, entitled "Criminales Dejan Mensaje." In this case Ana Maria Avila, 26, and her daughters Jackelyn Caroline, 9, Heidi Paola, 7, and Melia Elisabeth, 3, were murdered at the hands of three men that, according to several eyewitnesses, entered into their home one afternoon. Jackelyn aged nine was found in the laundry sink where, according to Prensa Libre's reporter, "she was presumably attempting to hide so she would not be murdered." This account is one of many that detailed the horrors of the crime and publicly recoiled at the murder of children. Yet, in the murders of Jackelyn, her sisters and mother, bureaucratic bungling and a turf war between the Ministerio Público and the National Police's division of criminal investigations meant that the crime scene was not investigated and that no material evidence was collected immediately following the crime- with the exception of a haunting signed note left by the perpetrators. According to the perpetrator, Jackelyn and her female kin were murdered as a "consequence" of a romantic betrayal perpetrated by her mother. The reasons why the victims drew the attention of her killers were amply covered in the media, but the effort to seek out the killers received little attention. At the end of December 2007, a profile of the perpetrator had been established by police but no arrests had been made and no suspects had been identified.

Guatemala's official response to the social ails that give rise to femicide- impunity, a cultural acceptance of gender inequality, and the presence of other pervasive forms of social inequalityhas been complex and centred, as Godoy-Paiz and Drysdale Walsh suggest, around the proliferation of agencies, institutions and laws to address some of femicide's legal supports. Institutional responses have also been geared to address, mainly rhetorically, legal inequities and the lack of opportunities available for the education, economic advancement, and political participation of young and ethnic women ${ }^{5}$ (Secretaría Presidencial de la Mujer, 2005).

President Colom's current approaches actively use the rhetoric of social justice. Soon after he took power, Colom centralized decision-making on social spending through the Social Cohesion Council (Consejo de Cohesión Social) which is headed by First Lady Sandra Torres de Colom. Centralizing decision-making on social spending according to Torres de Colom seeks social justice through concrete and targeted reductions in inequality (Gobierno de Álvaro Colom, 2008). One of the areas where the Colom government has hoped to reduce inequity is by addressing disparity in the legal consequences of gender-based violence. After the enactment of the legal changes, described in detail in Godoy-Paiz paper, Sandra Torres de Colom proudly suggested that she now knew that "women's lives would be respected as it is now something that is sought in law" (Gobierno de Guatemala, 2005). Such rhetorical support should work to suggest the government's commitment to redressing inequity and, as Drysdale Walsh in this collection rightly points out, to readjust the balance in civil rights. Unfortunately, the legal potential of these changes are not likely to impact the practice of impunity and thus are not likely to have an impact on the incidence of murders. Interestingly, new femicide laws provide many of

\footnotetext{
5 Examples of these types of policies and agencies are the Plan for Equal Opportunities (Plan de Equidad de Oportunidades) developed to cover the period from 1998-2001, or a variety of charity-like programs promoted by the First Lady's Social Works Secretariat (Secretaría de Obras Sociales de la Esposa del Presidente) since 1991 and aimed at addressing needs of girls and rural women as underprivileged sectors of the society (Secretaría Presidencial de la Mujer, 2005; SOSEP, 2008).
} 
the same protections already available to male murder victims who, as stated earlier, are killed ten times as often as women. Why is this type of legal redress of inequity ineffective at curbing the general practice of impunity?

\section{Local Understandings of Post-Conflict Violence}

The papers in this collection suggest that the construction of effective solutions to the region's post-conflict violence crisis needs to be situated beyond the legal and institutional realms. Addressing the current crisis of violence must consider inequity in the application of and access to the law, as Godoy-Paiz does in this issue, and the social practices through which violence and impunity becomes naturalized into culture/society discussed by both Menjivar and Drysdale Walsh in this issue. In essence, effective solutions to post-conflict violence need the deep understanding presented here of how violence is lived and mediated.

Menjivar's contribution presents an ethnographic account of the multiple ways through which violence comes to be incorporated into the everyday life of ladino women in a rural Guatemalan town. Looking at how women are hampered from accessing healthcare resources by poverty and how physical symptoms are clustered into ailments such as nervios or debilidad that can only be endured, Menjivar allows us to understand how male domination and violence is actively normalized by women themselves. This argument is furthered in her discussion of the violence of women's gossip as it is used by both men and women to scrutinize and discipline women's behaviors. She convincingly argues that understanding violence in this context is not just about understanding resource disparities but also about knowing how the local ways of speaking about and embodying violence are prone to misinterpretation. Menjivar's contribution to this collection suggests that violence is given cultural meaning as it is lived and mediated by social actors and as a result cannot be addressed outside the context of local "meaning-making". For Menjivar, understanding how a life with violence has become cultural norm is key to understanding the cultural supports for the problems of femicide that are taken up by Godoy-Paiz and Drysdale Walsh.

Godoy-Paiz analyses the discord between the current high level of legal supports for women's rights in Guatemala and women's increasing insecurity and physical vulnerability in Guatemala City. She argues that the legal reframing that has occurred with much foreign impetus and inspiration is inadequate to address the problem of gender violence as it is lived and practiced in the country. The focus on formal rights decreed by law instead of the local social conditions of poverty and impunity is incongruous with the design of more effective solutions that seek lives with social justice. For Godoy-Paiz, gender violence in Guatemala City is sustained by systemic impunity and poverty that forces victims of violence to accept threats, rapes, and assassinations. Drawing on insights from anthropological research on violence and inequality, she suggests that a reframing of the "gender violence problem" in Guatemala has to include an understanding of the processes through which both men and women come to socially support the presence of gender violence and impunity in their lives. Godoy-Paiz's study of Guatemala City residents shows how poverty, patriarchy and legacies of state-sponsored violence limit women's access to social justice both within and outside of the legal framework. For Godoy-Paiz, understanding the social supports of gender violence in Guatemala will not only serve to promote women's rights 
but it will also allow for an understanding of impunity systems and the everyday expressions of structural violence (Bourgois, 2004).

Drysdale Walsh looks at the way that Guatemalan civil society organizations and state have been hampered in addressing the increasing incidence of violence against women and argues that closer coordination between them and international donors would serve to better address the problems of gender violence. She looks at the difficulties caused by the division of labor amongst the eight public policy and justice sector institutional agencies currently defined by the Guatemalan state as responsible for addressing the different dimensions of gender violence. She also looks at how the lack of cohesion within the Guatemala's women's movement and its tense relationship with foreign funding agencies limit the effectiveness of this sector of civil society. Despite these caveats, Drysdale Walsh proposes that social justice can be forged for women in Guatemala by coordinating the admittedly flawed knowledge and practices of civil society and the state. Focusing on CONAPREVI (the National Coordinator for the Prevention of Intrafamiliar Violence and Violence against Women) as a case study of how effective civil society/state cooperation could take place, Drysdale Walsh shows how local understandings of violence from the grassroots rights organizations can be meshed with local institutional practices of the state to define more effective avenues for attaining social justice for women.

Social justice-inspired approaches to Central America's post-conflict violence must understand, as Godoy-Paiz does, that violence works at different levels and its multiple forms (gender, class, ethnic) are often superimposed and can be magnified. A social justice approach needs to privilege, as Menjivar does, the way that victims themselves come to understand and accept social violence - accepting, in Menjivar's example, inequality as "physical illnesses" instead of forms of abuse. Yet, it is not just violence that needs to be understood through a "local" lens. Drysdale Walsh and Menjivar show that institutional and individual approaches to the resolution of the region's crisis can have the opposite effect and inadvertently work to amplify violence. Understanding the particular reasons why states prefer to address inequality and violence through ineffective institutional and legal reforms can shed light on why impunity systems continue to function unabashed.

The local understandings (meaning-making practices) of violence and institutional practices in this collection are not just illustrative of a social reality lived in Guatemala but must be the basis upon which solutions to regional violence are crafted. As presented here, insights into the social life of violence-its victims, its meaning, and its reproduction and extension - can begin to suggest concrete ways to confront its injustice. 


\section{References}

Aguilar, A. L. (2005). Femicidio: La Pena Capital por ser Mujer. Diálogo, 4 (44), 1-5.

Berger, S. (2006). Guatemaltecas: The Women's Movement 1986-2003. Austin: University of Texas Press.

Bourdieu, P. (1997). Pascalian Meditations. Stanford: Stanford University Press.

Bourgois, P. (2004).US Inner-City Apartheid: The Contours of Structural and Interpersonal Violence. In

N. Scheper-Hugues \& P. Bourgois (eds.), Violence in War and Peace (pp. 301-308). Malden: Blackwell Publishing.

Caldeira, T. P.R. (2000). City of Walls: Crime, Segregation, and Citizenship in Sao Paulo. Berkeley: University of California Press.

Constantino, R. (2006). Femicide, Impunity and Citizenship. Chicana/Latina Studies, 6 (1) Fall. Department of Justice, Federal Bureau of Investigation (USA), Crime in the United States. Retrieved on May 15th, 2008 from http://www.fbi.gov/ucr/cius2006/data/table_16.html.

Estado de la Región (2008). Informe Estado de la Región en Desarrollo Humano Sostenible Costa Rica: Programa Estado de la Nación. San José, Costa Rica.

Fernández, D. (2008). La Trampa del Indulto: No Necesitamos Pena de Muerte, Sino Plena Certeza de la Persecución Penal. El Periodico. February 20, p. 32.

Galtung, J. (1969). Violence, Peace and Peace Research. Journal of Peace Research, 6, 167-191.

Gobierno de Álvaro Colom - 2008-2012 (2008). Presidente Colom Presenta al Consejo de Cohesión Social. Presidencia de la República de Guatemala. Guatemala City, Guatemala.

Gobierno de la República de Guatemala (2005). Política Nacional de Promoción y Desarrollo de las Mujeres Guatemaltecas y Plan de Equidad de Oportunidades 2001-2006. Guatemala: Secretaría Presidencial de la Mujer.

Godoy-Paiz, A. S. (2006). Popular Injustice: Violence, Community, and Law in Latin America. Stanford: Stanford University Press.

Grais-Targow, R. (2004). Femicide in Guatemala, BardPolitik, 5, 29-31.

Hernández Pico, J. (2005). Terminar la Guerra, Traicionar la Paz. Guatemala: Editorial de Ciencias Sociales.

Human Resources and Social Development Canada (2008). Indicators of Wellbeing in Canada: SecurityCrime Rates. Retrieved on May $15^{\text {th }}, 2008$ from http://www4.hrsdc.gc.ca/indicator.jsp?\&indicatorid=57\#MOREON_1

Kleinman, A., Das, V. \& Locke, M. (1997). Social Suffering: Essays. Berkeley: University of California Press.

Krujit, D. \& Koonings, K. (1999). Societies of Fear. London: Zed Press.

Menocal, C.(2006). 98\% de Asesinatos Quedan Inpunes. Prensa Libre. October 9, p. 12.

Moser, C. \& McIlwaine, C. (2001). Violence in a Post-Conflict Context: Urban Poor Perceptions from Guatemala. Washington: World Bank.

OCAVI (Observatorio Centroamericano sobre Violencia) (2007a). Tasas de Homicidios Dolosos en Centroamérica y República Dominicana por 100,000 Habitantes (1999 -2007). Retrieved on May 15th, 2008 from http://www.ocavi.com/docs_files/file_378.pdf.

OCAVI (Observatorio Centroamericano sobre Violencia) (2007b). Reporte de las Pandillas en El Salvador. Retrieved on May 15th, 2008 from http://www.ocavi.com/docs_files/file_423.pdf.

Plataforma de Investigación y Diálogo Intersectorial para el Diseño de una Política de Seguridad Ciudadana (POLSEC) (2004). Encuesta de Victimización y Percepción de Inseguridad en la Ciudad de Guatemala (Primera Encuesta), Vol. 2005. Guatemala: POLSEC (Plataforma de Investigación y Diálogo Intersectorial para el Diseño de una Política de Seguridad Ciudadana). 
Programa de las Naciones Unidas para el Desarrollo (PNUD) (2007a). Human Development Report Data 2007/2008. Retrieved in August 23rd, 2008 from http://hdrstats.undp.org/buildtables/rc_report.cfm.

Programa de las Naciones Unidas para el Desarrollo (PNUD) (2007b) Informe Estadístico de la Violencia en Guatemala. Retrieved on May 15th, 2008 from http://www.ocavi.com/docs_files/file_415.pdf.

Programa de las Naciones Unidas para el Desarrollo (PNUD) (2006). El Costo Económico de la Violencia en Guatemala. Retrieved on May 15th, 2008 from http://www.polsec.org/images/files/documentos/pdf/costoseconomicos.pdf .

Programa de las Naciones Unidas para el Desarrollo (PNUD) (2005). Cuanto Cuesta La Violencia en El Salvador? San Salvador: PNUD.

Rotker, S. (2002). Citizens of Fear: Urban Violence in Latin America. New Brunswick: Rutgers Univesity Press.

Russell, D. E. H. \& Van de Ven, N. (Eds.). (1976). Crimes against Women: Proceedings of the International Tribunal. Milbrae: Les Femmes Publishing.

Sanford, V. (2003). Buried Secrets. New York: Pallgrave McMillan.

Scheper-Hughes, N. (1992). Death Without Weeping: The Violence of Everyday Life in Brazil. Berkeley: University of California Press.

Secretaría Presidencial de la Mujer (2005). Acciones e Iniciativas para la Implementación del Enfoque de Género en el Ministerio de Educación. In Organization of Iberoamerican States Country Reports. Retrieved on May 15, 2008 from http://www.oei.es/genero/documentos_paises.htm.

SOSEP (Secretaría de Obras Sociales de la Esposa del Presidente) (2008). Misión y Objetívos. Gobierno de Alvaro Colom. Guatemala City: Guatemala.

United Nations Human Rights Commission (2005). Updated Set of principles for the protection and promotion of human rights through action to combat impunity. Sixty-first session, 8 February, Item 17 of the provisional agenda.E/CN.4/2005/102/Add.1

Vela, M., Senquén-Mónchez, A. \& Solares, H.A. (2001). El Lado Oscuro de la Eterna Primavera: Violencia, Criminalidad y Delincuencia en la Postguerra. Guatemala: FLACSO- Guatemala.

WOLA (2006). Youth Gangs in Central America: Issues in Human Rights, Effective Policing and Prevention. Washington, D.C: Washington Office on Latin America. 